\title{
Prevalence and indications for caesarean section in Enugu state, Nigeria
}

\author{
Hope O. Nwoga ${ }^{1 *}$, Miriam O. Ajuba², Chukwuma P. Igweagu ${ }^{2}$
}

\author{
${ }^{1}$ Department of Community Medicine, Enugu State University Teaching Hospital Park Lane Enugu, Nigeria \\ ${ }^{2}$ Department of Community Medicine, Enugu State University College of Medicine Enugu, Nigeria
}

Received: 26 August 2021

Accepted: 29 September 2021

\section{*Correspondence:}

Dr. Hope O. Nwoga,

E-mail: nwogahope@gmail.com

Copyright: ( ) the author(s), publisher and licensee Medip Academy. This is an open-access article distributed under the terms of the Creative Commons Attribution Non-Commercial License, which permits unrestricted non-commercial use, distribution, and reproduction in any medium, provided the original work is properly cited.

\begin{abstract}
Background: Caesarean section $(\mathrm{C} / \mathrm{S})$ is one of the commonly performed surgical procedures in obstetrics. This procedure has been on the increase in the past decade, creating a public health concern. The objective of this study was to determine the prevalence and predictors of C/S delivery in a tertiary health facility in Nigeria.

Methods: A prospective cohort study conducted at a tertiary health facility in Nigeria. Data was retrieved from the delivery cards of the mothers. Data was analysed using SPSS version 25 and variables were presented as frequencies, percentages, means, and standard deviation. Chi-square test was performed with the level of significance set at $\mathrm{p} \leq 0.05$. Binary logistic regression was used to determine factors that predicted $\mathrm{C} / \mathrm{S}$ delivery.

Results: The prevalence of $\mathrm{C} / \mathrm{S}$ was $48.3 \%$. Commonest indication for $\mathrm{C} / \mathrm{S}$ was 2 or more previous $\mathrm{C} / \mathrm{S}$. Mothers aged $>30$ years, employed, higher educational level, higher parity and delivered preterm predicted C/S delivery on logistic regression.

Conclusions: The prevalence of $\mathrm{C} / \mathrm{S}$ was high. Higher maternal age, employment, higher educational level, higher parity and preterm delivery were positively associated with $\mathrm{C} / \mathrm{S}$ delivery.
\end{abstract}

Keywords: Caesarean section, Enugu State, Nigeria, Prevalence, Tertiary health facility

\section{INTRODUCTION}

Caesarean section $(\mathrm{C} / \mathrm{S})$ is one of the oldest operations in surgery and also one of the commonly performed surgical procedures in obstetrics. ${ }^{1}$ Globally, the number of C/S has been on the rise over the last decade and this has been a source of major concern to healthcare providers in many developing and developed countries. This is so because $\mathrm{C} / \mathrm{S}$ is associated with increased risk of maternal/neonatal morbidity and mortality. ${ }^{2}$ It is estimated that about 20 million $\mathrm{C} / \mathrm{S}$ deliveries occur each year and this is increasing continuously in low, middle and high-income countries. $^{3}$ A study conducted between 2002 and 2012 showed that the rate of C/S increased from $18.2 \%$ in 2002 to $30.3 \%$ in 2012 , with the most common reason being the absence of a clear indication. ${ }^{4}$

In 1985, the World Health Organization (WHO) declared in Fortaleza, Brazil, that "There is no justification for any region to have a $\mathrm{C} / \mathrm{S}$ rate higher than $10-15 \%$ ". This position has been contested because the data on which the recommendation was based were limited and drawn primarily from northern European countries. ${ }^{6}$ In middle/low-income countries, the optimal $\mathrm{C} / \mathrm{S}$ rate is influenced by preferences regarding delivery, available medical services, family income, and the health care professionals' qualifications, as well as parents' educational level. ${ }^{7}$ In a more recent position statement, the WHO maintains that population-based $\mathrm{C} / \mathrm{S}$ rates $>10 \%$ are not associated with a reduction in maternal and neonatal mortality rates. ${ }^{1,8}$ Nonetheless, the world health body emphasises the need of C/S service provision to every woman in need of it regardless of the prevailing population-based rates. ${ }^{1,8}$ When medically indicated, C/S has the potential for reducing maternal/neonatal mortalities and morbidities including delivery complications such as obstetric fistula. ${ }^{1,8,9}$ However, a non-medically indicated $\mathrm{C} / \mathrm{S}$ has no associated additional 
benefits for mothers and new-borns, rather like any other surgery, it carries both short-term and/or long-term health risks. ${ }^{1,8,9}$

Some studies have been conducted on $\mathrm{C} / \mathrm{S}$ utilisation in Nigeria including a survey which examined the views of pregnant women and found that a high proportion of the study participants were averse to caesarean delivery. ${ }^{10}$ Thus, increase in $\mathrm{C} / \mathrm{S}$ is likely to be influenced by multiple additional factors, such as the financial status, underlying diseases, level of education, family/social environment, reproductive knowledge, media reports, feedback from social circles and medical staff, as well as the previous delivery experience. ${ }^{11}$ Despite the greater number of complications and risks of $\mathrm{C} / \mathrm{S}$ as compared to vaginal delivery, some women still tend to choose $\mathrm{C} / \mathrm{S}$. A report concluded that these women focused on a perceived benefit for their child, and overlooked the risk to themselves of going through a C/S. ${ }^{12}$

In Africa, $\mathrm{C} / \mathrm{S}$ is still performed in unfavourable conditions for saving the mother and foetus with 5 to 10 times higher maternal morbidity and mortality compared with vaginal delivery due to limited resources and far distance to a health facility for people living in rural areas. ${ }^{13}$ This escalating $\mathrm{C} / \mathrm{S}$ rate is a major public health problem because it increases the health risk for mothers and babies as well as the cost of health care compared with normal deliveries. ${ }^{14}$ While this increase has been attributed to the fear of litigation, more liberal use of $\mathrm{C} / \mathrm{S}$ for breech presentation, the detection of foetal distress by continuous electronic foetal monitoring, abdominal delivery of growth retarded infant, and improved safety of $\mathrm{C} / \mathrm{S}$ in developed countries; the reasons are less clear in developing countries. ${ }^{15}$ In Nigeria, for example, in spite of the high incidence of $\mathrm{C} / \mathrm{S}$ and increasing rate noted in many studies, there is paucity of literature with regard to the reason for such findings. ${ }^{15,16}$

Some of the reasons being adduced include, the specialist and referral nature of some of the hospitals, un-booked status of most of the patients, increasing use of foetal heart rate abnormalities alone as a measure of diagnosis of foetal distress in labour, over diagnosis of cephalo-pelvic disproportion by junior doctors, and use of repeat $\mathrm{C} / \mathrm{S}$ for patients with a previous $\mathrm{C} / \mathrm{S} .{ }^{14}$ Perinatal mortality rate shows no significant diminution despite the increasing $\mathrm{C} / \mathrm{S}$ rate. ${ }^{15}$ This increasing trend of $\mathrm{C} / \mathrm{S}$ might be stopped and even reversed without detriment to a continuing improvement in maternal and foetal health. ${ }^{16}$ This is particularly important in developing countries like Nigeria where large family size is a norm. Women also have great dislike for $\mathrm{C} / \mathrm{S}$ especially when there is no living child to show for it and would often try vaginal delivery at home or religious houses after a section thus predisposing themselves to uterine rupture with its resultant morbidity and mortality. It is proposed that careful probing of the trend and indications for the use of caesarean delivery may identify pathway to lower the C/S rate. ${ }^{17}$ The objective of this study was to determine the prevalence and predictors of $\mathrm{C} / \mathrm{S}$ delivery in a tertiary health facility in Nigeria.

\section{METHODS}

\section{Study design, area and population}

This was a prospective cohort study conducted at the Obstetrics and Gynecology (O and $\mathrm{G})$ Department of Enugu State University Teaching Hospital (ESUTH) Park Lane Enugu. ESUTH is one of the tertiary health institutions in Enugu State, Nigeria that provides tertiary services to the inhabitants of the State and its neighbouring state. It also serves as a referral center for both the government and privately owned health facilities within and outside the state. All the women that delivered at the (O and G) Department of ESUTH Park Lane Enugu within the period of data collection were used for the study.

\section{Data collection methods}

Data was collected for a period of 12 months (June 2020May 2021). The socio-demographic characteristics and modes of delivery including indications for $\mathrm{C} / \mathrm{S}$ were retrieved from the ante natal and delivery cards and entered into a pro forma. Two research assistants (clinical medical students) were used for data collection. They were trained on the data to be retrieved and how to retrieve them from the clients' cards. Each morning they retrieve the folders of the women that delivered the previous day and fill in the data in a structured pro forma. This was done before the folders were taken to the central card room to avoid loss of information or missing cards.

\section{Data analysis}

All the data were imputed into IBM Statistical Package for Social Sciences (SPSS) version 25 and edited for errors by generating frequencies. Categorical variables were summarized using frequencies and percentages. Chisquared test was used to test for associations between variables with significant level placed at $p \leq 0.05$. Binary logistic regression was used to determine the predictors of $\mathrm{C} / \mathrm{S}$ delivery. Odds ratio together with their corresponding $\mathrm{p}$ values and confidence intervals were computed at a $5 \%$ error rate.

\section{RESULTS}

There were $758 \mathrm{C} / \mathrm{S}$ out of the 1568 deliveries within the 12 months that was studied giving a C/S rate of $48.3 \%$. About $15.1 \%$ were elective while $33.2 \%$ were emergency $\mathrm{C} / \mathrm{S}$.

Table 1 shows the socio-demographic and obstetric characteristic of the studied mothers. Most of them were aged 21-30 years 878 (56.0\%). Almost all of them were married 1519 (96.9\%), Igbos 1554 (99.2\%) and Christians $1560(99.5 \%)$. Most of them were civil servants 869 $(55.4 \%)$, had tertiary education $984(62.8 \%)$ and of low 
parity $1082(69.0 \%)$. Majority delivered at term 1251 $(79.8 \%)$ and were booked $1266(80.7 \%)$.

Table 2 shows the modes of delivery. About half of the women delivered through SVD $810(51.7 \%)$ while about one third $522(33.2 \%)$ delivered through emergency C/S.

Figure 1 shows the indications for C/S delivery. Two or more previous $\mathrm{C} / \mathrm{S}$ was the commonest indication for $\mathrm{C} / \mathrm{S}$.

Table 3 shows factors that affected C/S delivery. Maternal age, occupation, educational level, gestational age at delivery and booking status significantly affected $\mathrm{C} / \mathrm{S}$ delivery.

Table 1: Socio-demographic and obstetrics characteristics of the mothers.

\begin{tabular}{|ll|l|}
\hline Variables & $\begin{array}{l}\text { Frequency } \\
\mathbf{N}=1568\end{array}$ & Percentage \\
\hline Age (years) & \multicolumn{2}{|l|}{} \\
\hline Mean \pm SD & $29.78 \pm 4.70$ \\
\hline Age in groups (years) & \\
\hline$\leq 20$ & 30 & 1.9 \\
\hline $21-30$ & 878 & 56.0 \\
\hline $31-40$ & 646 & 41.2 \\
\hline $41-50$ & 14 & 0.9 \\
\hline Marital status & & \\
\hline Married & 1519 & 96.9 \\
\hline Single & 49 & 3.1 \\
\hline Ethnicity & & \\
\hline Igbo & 1554 & 99.2 \\
\hline Yoruba & 2 & 0.1 \\
\hline Hausa & 10 & 0.6 \\
\hline Others & 2 & 0.1 \\
\hline Religion & & \\
\hline Christianity & 1560 & 99.5 \\
\hline Islam & 8 & 0.5 \\
\hline Occupation & & \\
\hline
\end{tabular}

\begin{tabular}{|lll|}
\hline Variables & $\begin{array}{l}\text { Frequency } \\
\text { N=1568 }\end{array}$ & Percentage \\
\hline Civil servants & 869 & 55.4 \\
\hline Agricultural workers & 12 & 0.8 \\
\hline Crafts and related trades & 171 & 10.9 \\
\hline Unskilled workers & 24 & 1.5 \\
\hline Unemployed & 492 & 31.4 \\
\hline Educational level & & \\
\hline Tertiary & 984 & 62.8 \\
\hline Secondary completed & 574 & 36.6 \\
\hline Primary completed & 10 & 0.6 \\
\hline Parity & & \\
\hline 1-2 & 1082 & 69.0 \\
\hline 3-4 & 400 & 25.5 \\
\hline Above 4 & 86 & 5.5 \\
\hline GA at delivery & & \\
\hline Term & 1251 & 79.8 \\
\hline Preterm & 195 & 12.4 \\
\hline Post date & 122 & 7.8 \\
\hline Booking status & & \\
\hline Booked & 1266 & 80.7 \\
\hline Un-booked & 302 & 19.3 \\
\hline GA- gestational age & & \\
\hline
\end{tabular}

Table 2: Mode of delivery.

\begin{tabular}{|lll|}
\hline Mode of delivery & Frequency & Percentage \\
\hline SVD & 810 & 51.7 \\
\hline Elective C/S & 236 & 15.1 \\
\hline Emergency C/S & 522 & 33.2 \\
\hline
\end{tabular}

SVD- Spontaneous vertex delivery

Table 4 shows the predictors of C/S delivery. Maternal age, employment status, educational level and gestational age at delivery predicted C/S delivery. Delivery at $<37$ weeks gestational age had about 2 times odd of $\mathrm{C} / \mathrm{S}$ delivery when compared to delivery at $\geq 37$ weeks gestational age.

Table 3: Factors that affect CS delivery.

\begin{tabular}{|lllll|}
\hline Variable & SVD & C/S & $\chi^{2}$ & P value \\
\hline Age in group (years) & & & 24.424 & $<0.001^{*}$ \\
\hline$\leq 20$ & $13(43.3)$ & $17(56.7)$ & & \\
\hline $21-30$ & $498(56.7)$ & $380(43.3)$ & & \\
\hline $31-40$ & $289(44.7)$ & $357(55.3)$ & & 0.067 \\
\hline $41-50$ & $10(71.4)$ & $4(28.6)$ & 3.361 & 0.232 \\
\hline Marital status & & & & \\
\hline Married & $791(52.1)$ & $728(47.9)$ & & \\
\hline Single & $19(38.7)$ & $30(61.2)$ & & \\
\hline Ethnicity & & & & \\
\hline Igbo & $802(51.6)$ & $752(48.4)$ & & \\
\hline Yoruba & $2(100.0)$ & $0(100.0)$ & & \\
\hline Hausa & $6(60.0)$ & $4(40.0)$ & $2(100.0)$ & \\
\hline Others & $0(0.0)$ & & & \\
\hline
\end{tabular}




\begin{tabular}{|c|c|c|c|c|}
\hline Variable & SVD & $\mathrm{C} / \mathrm{S}$ & $\chi^{2}$ & P value \\
\hline \multicolumn{5}{|l|}{ Religion } \\
\hline Christianity & $804(51.5)$ & $756(48.5)$ & 1.754 & 0.185 \\
\hline Islam & $6(75.0)$ & $2(25.0)$ & & \\
\hline \multicolumn{5}{|l|}{ Occupation } \\
\hline Civil servants & $427(48.9)$ & $446(51.1)$ & 11.077 & $0.026^{*}$ \\
\hline Agricultural workers & $6(50.0)$ & $6(50.0)$ & & \\
\hline Crafts and related trades & $93(54.4)$ & $78(45.6)$ & & \\
\hline Unskilled workers & $8(33.3)$ & $16(66.7)$ & & \\
\hline Unemployed & $276(56.6)$ & $212(43.4)$ & & \\
\hline \multicolumn{5}{|l|}{ Educational level } \\
\hline Tertiary & $532(54.1)$ & $452(45.9)$ & 6.755 & $0.034 *$ \\
\hline Secondary completed & $272(47.4)$ & $302(52.6)$ & & \\
\hline Primary completed & $6(60.0)$ & $4(40.0)$ & & \\
\hline \multicolumn{5}{|l|}{ Parity } \\
\hline $1-2$ & $555(51.3)$ & $527(48.7)$ & 1.671 & 0.434 \\
\hline $3-4$ & $215(53.8)$ & $185(46.3)$ & & \\
\hline Above 4 & $40(46.5)$ & $46(53.5)$ & & \\
\hline \multicolumn{5}{|l|}{ GA at delivery } \\
\hline Term & $675(54.0)$ & $576(46.0)$ & 23.617 & $<0.001 *$ \\
\hline Preterm & $69(35.4)$ & $126(64.6)$ & & \\
\hline Post date & $66(54.1)$ & $56(45.9)$ & & \\
\hline \multicolumn{5}{|l|}{ Booking status } \\
\hline Un-booked & $127(42.1)$ & $175(57.9)$ & 13.819 & $<0.001 *$ \\
\hline Booked & $683(53.9)$ & $583(46.1)$ & & \\
\hline
\end{tabular}

Table 4: Binary logistic regression showing predictors of C/S delivery.

\begin{tabular}{|c|c|c|c|c|}
\hline \multirow{2}{*}{ Variable } & \multirow{2}{*}{ Odds ratio } & \multirow{2}{*}{$P$ value } & \multicolumn{2}{|c|}{ 95\% CI for odds ratio } \\
\hline & & & Lower & Upper \\
\hline \multicolumn{5}{|l|}{ Age (years) } \\
\hline$\leq 30$ & 0.608 & $<0.001 *$ & 0.488 & 0.756 \\
\hline$>30$ & 1 & & & \\
\hline \multicolumn{5}{|l|}{ Marital status } \\
\hline Married & 0.763 & 0.403 & 0.404 & 1.439 \\
\hline Single & 1 & & & \\
\hline \multicolumn{5}{|l|}{ Employment status } \\
\hline Employed & 1.276 & $0.046^{*}$ & 1.004 & 1.622 \\
\hline Unemployed & 1 & & & \\
\hline \multicolumn{5}{|l|}{ Educational level } \\
\hline Secondary and above & 1.280 & $0.032 *$ & 1.022 & 1.603 \\
\hline$<$ Secondary & 1 & & & \\
\hline \multicolumn{5}{|l|}{ Parity } \\
\hline $1-2$ & 0.777 & $0.042 *$ & 0.610 & 0.991 \\
\hline Above 2 & 1 & & & \\
\hline \multicolumn{5}{|l|}{ GA at delivery } \\
\hline$<37$ weeks & 1.942 & $<0.001^{*}$ & 1.393 & 2.708 \\
\hline$\geq 37$ weeks & 1 & & & \\
\hline \multicolumn{5}{|l|}{ Booking status } \\
\hline Un booked & 1.255 & 0.125 & 0.939 & 1.677 \\
\hline Booked & 1 & & & \\
\hline
\end{tabular}

*Significant values 


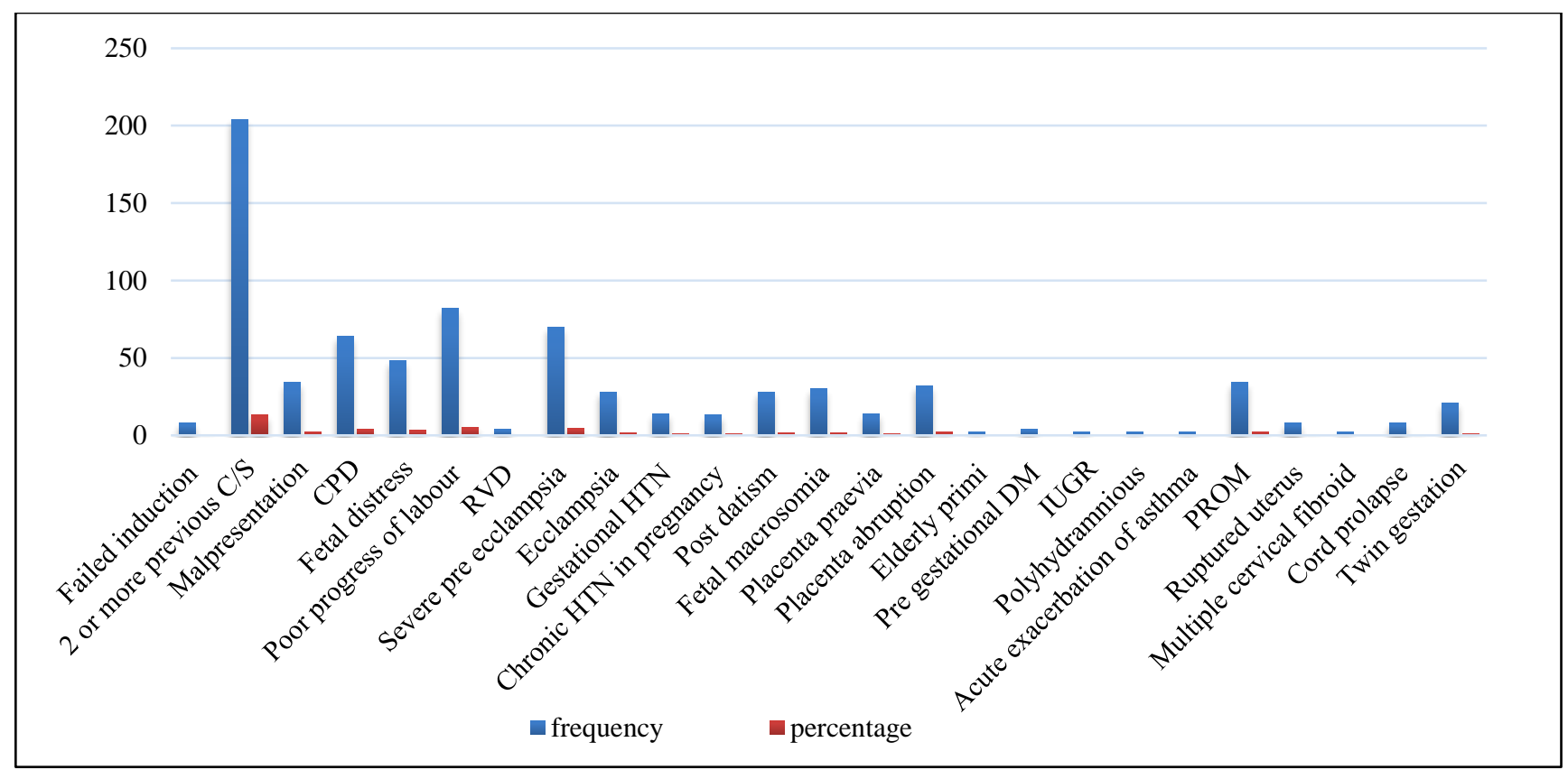

CPD- Cephalo-pelvic disproportion; RVD- retroviral disease; HTN- hypertension; DM- diabetes; PROM- premature rupture of membrane.

Figure 1: Indications for C/S delivery.

\section{DISCUSSION}

The prevalence of $\mathrm{C} / \mathrm{S}$ in this study was $48.3 \%$ and is far much higher than the $10-15 \%$ recommended by the WHO for developing countries. ${ }^{18}$ This may suggest an overuse of the procedure in the studied population. Some reports have also supported this indicating that there is overuse of this procedure in many parts of the world. ${ }^{19,20}$ It may also be due to proximity of the hospital as a referral centre for both private and other government owned facilities within and outside the state. Additionally there may be a dilution effect as majority of the mothers with low risk pregnancies deliver at the primary or secondary health facilities. Similar studies in Nigeria, Pakistan and Greece reported similar higher findings. ${ }^{14,15,21,22}$ The frequency of C/S may depend on the socio-demographic and obstetrics characteristics of the population, referral role of the hospital, departmental policies regarding management of such cases as dystocia, breech, foetal distress and previous $\mathrm{C} / \mathrm{S}$, physician factor, medico-legal aspects, and consideration of maternal choice. ${ }^{14}$

About $68.7 \%$ of the $\mathrm{C} / \mathrm{S}$ were through emergency $\mathrm{C} / \mathrm{S}$. Similar findings have been reported in other parts of Nigeria. ${ }^{23}$ This may be due to the strong aversion to $\mathrm{C} / \mathrm{S}$ in our environment due to religious, cultural, or socioeconomic factors and superstitious beliefs. ${ }^{23}$ It could also be attributed to the fact that this is a referral centre where complicated cases from both primary and secondary health facilities are managed. The commonest indications for $\mathrm{C} / \mathrm{S}$ was 2 or more previous C/S (13.0\%). This is similar to the $12 \%$ reported from Sagamu Nigeria but lower than the $16 \%$ reported from Ethiopia. ${ }^{15,24}$ Previous C/S has been reported as the highest single indication for repeat section because obstetricians regard vaginal birth after previous $\mathrm{C} / \mathrm{S}$ as a high-risk option. However, trial of labour under close monitoring in carefully selected patient is now increasingly being advocated. Additionally, it is reported that $64.8-86.0 \%$ of patients with a C/S who were allowed for trial of labour delivered without any complication. ${ }^{25}$

On logistic regression mothers aged above 30 years are more likely to deliver through $\mathrm{C} / \mathrm{S}$ than those younger. Older women have more chance of a prior $\mathrm{C} / \mathrm{S}$, which leads them to high chance of another $\mathrm{C} / \mathrm{S}$. This finding agrees with studies conducted in India, Vietnam and Ethiopia where those aged 30 years and above are at least two times more likely to have C/S delivery. ${ }^{26-28}$ Women that are employed and with higher educational level have higher odds of having C/S. Other studies corroborated this. $^{26,27}$ These factors are associated with financial independence and better decision making. They are also more likely to use health facilities. A study in India showed that economic status and woman's financial autonomy are associated with institutional delivery. ${ }^{29}$ Mothers with lower parity (1-2) are less likely to have a $\mathrm{C} / \mathrm{S}$ when compared to those with higher parity. Women with higher parity may have had previous $\mathrm{C} / \mathrm{S}$ predisposing them to another $\mathrm{C} / \mathrm{S}$ as previous $\mathrm{C} / \mathrm{S}$ was the commonest indication for $\mathrm{C} / \mathrm{S}$ delivery in this study.

Preterm delivery had about 2 times odd of C/S. This was not surprising as vaginal delivery have been noted to worsen perinatal outcome and even predispose to brain injury in premature babies. ${ }^{30}$ Another study also reported positive association between preterm birth and $\mathrm{C} / \mathrm{S}$ delivery. ${ }^{31}$ Un-booked mothers have higher odds of $\mathrm{C} / \mathrm{S}$ delivery when compared to booked mothers. This may be 
because most un-booked cases present as complicated cases that need immediate delivery of the baby leading to increased $\mathrm{C} / \mathrm{S}$ delivery. Conversely, a similar study reported that $\mathrm{ANC}$ attendance and booked cases were more likely to have a $\mathrm{C} / \mathrm{S}$ delivery. ${ }^{28}$ Maternal choice and physician factor may explain the difference.

\section{CONCLUSION}

The prevalence of C/S is high in Enugu State. The study demonstrated that higher maternal age, employment, higher educational level, higher parity and preterm delivery predicted $\mathrm{C} / \mathrm{S}$ delivery. Efforts should be intensified to address these risk factors.

Funding: No funding sources

Conflict of interest: None declared

Ethical approval: The study was approved by the Institutional Ethics Committee ESUTH Park Lane

\section{REFERENCES}

1. Fenton PM, Whitty CJM, Reynolds F. Caesarean section in Malawian; prospective study of early maternal and perinatal mortality. Brit Med J. 2003;327:587-98.

2. Roberts CL, Nippita TA. International caesarean section rates: the rising tide. Lancet Glob Health. 2015;3(5):e241-2.

3. Luz G, Belizán JM, Lauer JA, Betrán AP, Merialdi M, Althabe F. The global numbers and costs of additionally needed and unnecessary caesarean sections performed per year: overuse as a barrier to universal coverage. World Health Report. 2010;30.

4. Al Rifai R. Rising cesarean deliveries among apparently low-risk mothers at university teaching hospitals in Jordan: analysis of population survey data, 2002-2012. Glob Health Sci Pract. 2014;2(2):195-209.

5. World Health Organization Human Reproduction Programme. WHO statement on caesarean section Rates. Reprod Health Matters. 2015;23:149-50.

6. Baron YM. Does the $10-15 \%$ caesarean section rate threshold established by the WHO in 1985 still apply for modern obstetrics in developed countries? Eur J Obstet Gynecol Reprod Biol 2016;206:e81.

7. Betrán AP, Ye J, Moller AB, Zhang J, Gülmezoglu $\mathrm{AM}$, Torloni MR. The increasing trend in caesarean section rates: Global, regional and national estimates: 1990-2014. PLoS One. 2016;11:e0148343.

8. Betran AP, Torloni MR, Zhang JJ. WHO Statement on Caesarean Section Rates. BJOG. 2016;123:667-70.

9. Keag OE, Norman JE, Stock SJ. Long-term risks and benefits associated with caesarean delivery for mother, baby, and subsequent pregnancies: Systematic review and meta-analysis. PLoS Med. 2018;15:e1002494

10. Sunday-Adeoye I, Kalu CA. Pregnant Nigerian women's view of caesarean section. Niger J Clin Pract. 2011;14:276-9.
11. Loke AY, Davies L, Li SF. Factors influencing the decision that women make on their mode of delivery: The health belief model. BMC Health Serv Res. 2015; 15:274.

12. Litorp H, Mgaya A, Kidanto HL, Johnsdotter S, Essén B. "What about the mother?" Women's and caregivers' perspectives on caesarean birth in a lowresource setting with rising caesarean section rates. Midwifery. 2015;31:713-20.

13. Shearer EL. Cesarean section: medical benefits and costs. Soc Sci Med. 2011;37(10):1223-31.

14. Naymi RS, Rehan N. Prevalence and determinants of caesarean section in a Teaching Hospital of Pakistan. J Obstet Gynaecol. 2000;20:479-83.

15. Oladapo OT, Sotunsu JO, Sule-Odu AO. The rise in caesarean birth rate in Sagamu, Nigeria: reflection of changes in obstetrics practice. J Obstet Gynaecol. 2004;24:377-81.

16. Njokanma FO, Egri-Okwargi MT, Nwokoro CA, Orebamjo T, Okeke GC. Birth asphyxia, perinatal and maternal mortality associated with caesarean section. Trop J Obstet Gynaecol. 2002;19:25-9.

17. Notzon FC, Cnattingius S, Bergijo P, Cole S, Taffel $\mathrm{S}$, Irgens $\mathrm{L}$, et al. Caesarean section delivery in the 1980s; International comparison by indication. Am J Obstet Gynaecol. 1994;170:495-504.

18. World Health Organization. Appropriate technology for birth. Lancet. 1985:2:436-7.

19. Gibbons L, Belizán JM, Lauer JA, Betrán AP, Merialdi M, Althabe F. The global numbers and costs of additionally needed and unnecessary caesarean sections performed per year: overuse as a barrier to universal coverage. Background Paper 30, World Health Report 2010;30(1):1-31.

20. Shah A, Fawole B, M'Imunya. Caesarean delivery outcomes from the WHO global survey on maternal and perinatal health in Africa. Int J Gynecol Obstet. 2009; 107:191-7.

21. Aisien AO, Lawson JO, Adebayo AA. A five year appraisal of caesarean section in a Northern Nigeria University Teaching Hospital. Niger Postgrad Med J. 2002;9:146-50.

22. Vivilaki V, Antoniou E. Caesarean section: the underpinning choice? Health Sci J. 2008;2(2):83-8.

23. Obum JA, Ugboma HAA, Ejikeme BN, Umeora OUJ, Agwu UM. Pattern and outcome of higher order caesarean section in a secondary health facility in Nigeria. Res Obstet Gynaecol. 2012;1(3):19-22.

24. Ali Y. Analysis of caesarean delivery in Jimma Hospital, south-western Ethiopia. East Afr Med J. 1995;72:60-3.

25. Tunar MJ. Delivery after one previous caesarean section. Am J Obstet Gynaecol. 1997;176:741-4.

26. Lumbiganon $\mathrm{P}$, Laopaiboon $\mathrm{M}$, Gülmezoglu AM. Method of delivery and pregnancy outcomes in Asia: the WHO global survey on maternal and perinatal health 2007-08. Lancet. 2010;375:490-9.

27. Toan TK, Eriksson B, An PN, Chuc NTK, Bongjers G, Gottvall K. Technology preference in choices of delivery care utilization from user perspective-a 
community study in Vietnam. Am J Public Health Res. 2013;1(1):10-7.

28. Bayou YT, Mashalla YJS, ThupayagaleTshweneagae G. Patterns of caesarean-section delivery in Addis Ababa, Ethiopia. Afr J Prm Health Care Fam Med. 2016;8(2):a953.

29. Kawungenzi PC, AkiiBua D, Alenei C. Attendance and utilization of antenatal care services: Multi-center study in upcoming areas of Uganda. Open J Prevent Med. 2015;5(3):132-42.
30. Howson CP, Kinney MV, McDougall L. Born too soon: preterm birth matters. Reprod Health. 2013;10(1):S1

31. Nwoga HO, Ajuba MO, Igweagu CP. Born too soon; implications in a tertiary health facility in Enugu State Nigeria. Int J Health Sci Res. 2021;11(6):190-6.

Cite this article as: Nwoga $\mathrm{HO}$, Ajuba MO, Igweagu CP. Prevalence and indications for caesarean section in Enugu state, Nigeria. Int $\mathbf{J}$ Reprod Contracept Obstet Gynecol 2021;10:4059-65. 